\title{
The Role of the Portal Circulation in Glucose and Fructose Tolerance
}

\author{
N. McIntyre, D.S. Turner and C.D. Holdsworth \\ Medical Unit, Royal Free Hospital, London, W.C. 1, Great Britain
}

Received: February 12, 1970

Summary. Infusion of fructose into the portal vein of anaesthetized dogs gave arterial plasma fructose levels which were much lower than those obtained with infusion of the same amount of fructose into a systemic vein. In contrast, when glucose was infused mean arterial blood glucose levels were similar for the two routes of administration. - These results indicate that significant hepatic removal of fructose occurs during the first portal circulation, and is sufficient to explain the lower levels of plasma fructose which follow oral, compared with intravenous, administration of the sugar. In the case of glucose, however, the results do not support the view that the superiority of oral over intravenous tolerance is due simply to hepatic uptake of large amounts of glucose presented to the liver by the portal circulation.

Le rôle de la circulation portale dans la tolérance au glucose et au fructose

Résumé. L'infusion de fructose dans la veine porte de chiens anesthésiés produit des concentrations de fructose dans le plasma artériel inférieures à celles obtenues après l'infusion d'une même quantité de fructose dans une veine superficielle. Au contraire, l'infusion de glucose provoquait des taux artériels moyens de glucose très similaires, par les deux voies d'administration. - Ces résultats indiquent qu'une quantité considérable de fructose disparaît pendant la première circulation portale. Ce qui est suffisant pour expliquer les taux plasmatiques de fructose plus bas après l'administration orale du sucre, comparés aux résultats obtenus après l'administration intraveineuse. Les résultats obtenus après l'administration de glucose n'étayent pas l'opinion qu'une tolérance supérieure obtenue par voie orale est uniquement causée par une adsorption hépatique des quantités considérables de glucose présentées au foie par la circulation portale.

Die Rolle des Pfortaderkreislaufs fiur die Glucose-und Fructose-Toleranz

Zusammenfassung. Die arteriellen Plasma-Fructose Spiegel lagen bei narkotisierten Hunden nach FructoseInfusion in die Pfortader wesentlich niedriger als nach Infusion der gleichen Fructosemenge in eine periphere Vene. Im Gegensatz dazu stimmten die mittleren arteriel. len Blutzuckerspiegel nach Glucoseinfusionen über beide Routen weitgehend überein. - Die Befunde deuten dar. auf hin, daß die Leber bei der ersten Passage des Pfort. aderblutes eine signifikante Menge Fructose aufnimmt, und sie reichen aus, um zu erklären, warum nach oraler Verabreichung von Fructose niedrigere Plasma-FructoseSpiegel als nach intravenöser Zufuhr zu beobachten sind. Im Falle der Glucose liefern die Daten jedoch keine Stütze für die Ansicht, daß die orale Toleranz die intravenöse lediglich wegen der Aufnahme großer Glucosemengen durch die Leber aus dem Pfortaderangebot übertrifft.

Key-words: Glucose, fructose, portal circulation, liver, carbohydrate tolerance.

\section{Introduction}

It has been recognized for many years that the blood levels of glucose or fructose which are attained following oral administration are less than those attained with intravenous administration of the same amount of these sugars. The liver is capable of assimilating of both substances and the anatomical relationship between the intestine, portal circulation and liver has led naturally to the assumption that the liver is of particular importance in the removal, from the portal blood, of glucose and fructose absorbed by the intestine [11].

In rats Cori and Cori [1] found that the degree of fructosuria with peripheral venous infusion was almost twice as great as that which resulted when fructose was infused into the portal vein. De Filippi $[2,3]$ and Jacobson [6] noted that portacaval anastomosis in dogs led to a striking increase in fructosuria after oral administration of the sugar. Both of these observations support the suggestion that a large proportion of an ingested load of fructose is removed during its initial passage through the liver and does not reach the systemic cireulation.
In the case of glucose, however, no direct experiments have been performed similar to the fructose experiments of Cori and Cori. Portacaral anastomosis produced only a slight impairment in glucose tolerance as assessed by degree of glycosuria $[2,3,6]$. It has recently been established that the plasma insulin response to oral glucose is much higher than that resulting from intravenous glucose [8]. The increased peripheral utilization of glucose which would result from the higher insulin levels could explain the superiority of oral over intravenous glucose tolerance without the necessity of postulating that a large amount of absorbed glucose is removed from the portal blood on its first hepatic passage.

In order to assess the importance of the portal circulation in determining the blood sugar response to oral administration of glucose and fructose these sugars have been infused into dogs. On one occasion a systemic vein was used and on another occasion the same amount of sugar was given through a portal venous radicle. Tolerance was assessed by measurement of arterial blood sugar levels during infusion. It was anticipated that if a significant amount of sugar was re- 
moved by the liver on the first passage arterial sugar levels would be much lower with intraportal infusion than with systemic administration. The results obtained are presented in this paper.

\section{Materials and Methods}

Experiments were performed on animals of a variety of breeds weighing between 14.5 and $32 \mathrm{~kg}$. For at least three days before the first experiment, and thereafter, they were fed on a protein-rich diet of proprietary dog foods mixed with ox heart, full cream milk, and a small amount of potato. Access was allowed to dog biscuits.

Experiments were performed after an overnight fast. The animals were anaesthetized with intravenous pentobarbitone sodium. An initial dose of $30 \mathrm{mg} / \mathrm{kg}$ was used; further doses of $60-120 \mathrm{mg}$ were given if the anaesthetic state lightened.

Systemic intravenous infusions were given through a cannula or catheter in a limb vein. Intraportal infusions were given through a catheter inserted into a mesenteric venous radicle. Arterial blood samples were taken from an indwelling Riley needle placed in a femoral artery. Following insertion of needles and cannulae the animals were allowed to "equilibrate" for at least thirty minutes. Glucose and fructose were infused as 5\% solutions. Each animal received two infusions of the same amount of sugar at the same constant rate at an interval of 5-14 days. Fructose was infused at a rate of $300 \mathrm{mg} / \mathrm{min}$ into all four animals (weight from 22 to $28 \mathrm{~kg}$ ) given fructose. Glucose infusion rates varied in the nine animals studied from $290-840 \mathrm{mg} / \mathrm{kg} / \mathrm{h}$. In five of the animals the intravenous infusion was given first; in the others the order was reversed and the intraportal preceded the intravenous infusion. A sham operation with opening of the peritoneal cavity was performed before the intravenous infusion.

Arterial blood samples were taken before the start of the sugar infusions and then at predetermined intervals. Heparinized tubes were used for collection and an aliquot was pipetted immediately into $0.33 \mathrm{M}$ perchloric acid for subsequent glucose estimation. The remainder was kept in crushed ice until centrifugation; the plasma was stored at $-15^{\circ} \mathrm{C}$ until insulin and fructose estimations were performed.

Blood glucose was measured by a glucose oxidase method [5]. Fructose was measured by the method of Higashi and Peters [4] for inulin omitting the first stage which is the hydrolysis of inulin to fructose. Plasma insulin was measured by radioimmunoassay using immunoprecipitation for separation of bound and free insulin [10]. Serial dilutions of dog insulin were found to assay in parallel with human insulin; as dog insulin was not available as a standard, results have been expressed as $\mu$ Unit equivalents of human insulin per millilitre.

\section{Results}

Intraportal and intravenous fructose infusions. The results are presented as mean values in Fig. 1. In each

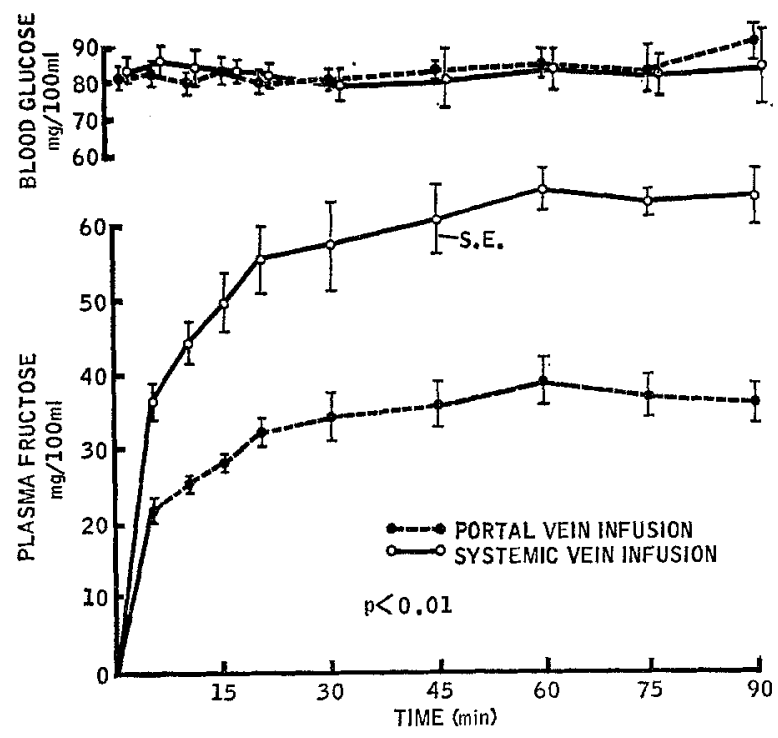

Fig. 1. Mean arterial plasma fructose and arterial blood glucose levels with constant infusion of $5 \%$ fructose into anaesthetized dogs. Each animal received one infusion of fructose into a portal venous radicle and another into a systemic vein

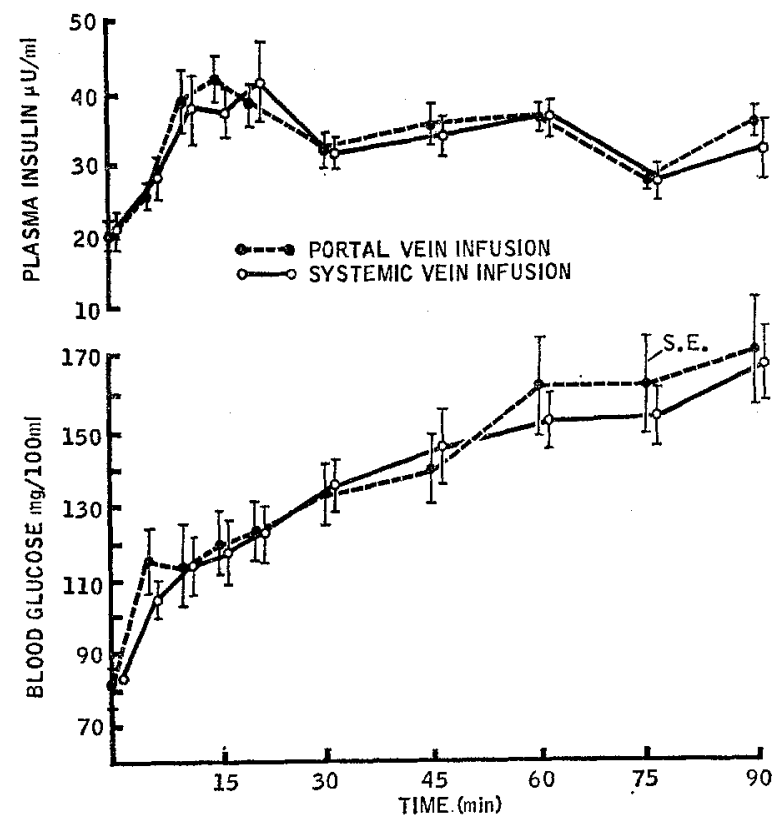

Fig. 2. Mean arterial blood glucose and arterial plasma insulin levels with constant infusion of $5 \%$ glucose into anaesthetized dogs. Each animal received one infusion of glucose into a portal venous radicle and another into a systemic vein

of four experiments the plasma fructose levels during intravenous infusions were much higher than those attained during intraportal infusion. After fifteen minutes the difference was not less than $20 \mathrm{mg} / 100 \mathrm{ml}$ in 
any of the animals, and in one dog a difference of $33 \mathrm{mg} / 100 \mathrm{ml}$ was found at thirty minutes. An interesting feature of each infusion was the plateau which was reached with both routes of infusion; after thirty minutes little variation in plasma fructose levels occurred with time.

Blood glucose levels during fructose infusion showed no constant change. In three animals the blood glucose did not rise more than $8 \mathrm{mg} / 100 \mathrm{ml}$ above the levels found before the start of the fructose infusion. In none of the animals did the blood glucose fall more than $11 \mathrm{mg} / 100 \mathrm{ml}$ below the preinfusion level. In one dog, however, there was a definite rise in blood glucose at the end of the intraportal fructose to $123 \mathrm{mg} / 100 \mathrm{ml}$; no such rise accompanied the intravenous infusion.

Intraportal and intravenous glucose infusion. The experimental results are given as mean values in Fig. 2. In contrast to the findings with fructose, mean blood levels of glucose were almost identical with the two routes of administration. Mean blood glucose levels continued to rise slowly during the whole of the $90 \mathrm{~min}$ infusion. Plasma insulin concentrations were also similar with both routes of infusion. After an initial peak at approximately twenty minutes the levels fell slightly but remained elevated.

\section{Discussion}

Our finding in dogs that arterial blood fructose levels were lower with intraportal than with intravenous infusion of the sugar confirms the observation of Cori and Cori [1] who conducted a similar study in rats. Both results support the hypothesis that hepatic removal of fructose during the first portal circulation is an important factor in determining the low plasma fructose levels found after oral administration.

In the case of glucose no clear difference in tolerance could be demonstrated with intravenous and intraportal infusion of the sugar. The similarity of the blood glucose response with both routes of administration suggests that oral glucose tolerance may be relatively little affected by the anatomical relationship between the portal vein and the liver. This does not imply that the liver is quantitatively unimportant in the disposal of a glucose load, whether administered intravenously or orally, but only that the proportion of glucose taken up by the liver may be relatively independent of the concentration of glucose in the portal blood perfusing the liver.

In these experiments infusion of glucose intraportally does not of course reproduce the physiological effects of oral administration as the plasma insulin response would be much greater with transport of glucose through the intestinal wall [8]. It is interesting to speculate on the effect which this enhancement of insulin secretion would have on the proportion of absorbed glucose which would be utilized by the liver. The increase in portal insulin concentration might stimulate hepatic glucose uptake, thus increasing the amount taken up by the liver; it is equally possible, however, that the elevated peripheral insulin levels might so enhance glucose uptake by muscle and adipose tissue that the relative contribution of the liver to the disposal of a glucose load might be diminished. To our knowledge no direct experiments have been done to test these alternative hypotheses. Despite this, several workers have assumed, uncritically, that hepatic uptake is the major factor which accounts for the difference between oral and intravenous glucose tolerance; by so doing they have made errors in the interpretation of their experimental data.

Scow and Cornfield [1] calculated the amount of glucose taken up by rat liver following an oral glucose load using the assumption that the disposal rate of glucose from the peripheral circulation was the same whether the glucose had been given orally or intravenously; Janes and Osburn [7] used a similar argument in studies on rats and rabbits. More recently Perley and Kipnis [9], in studies on man, argued that "the intravenous load required to duplicate the oral blood glucose profile can be taken as a close approximation of the quantity of glucose escaping initial hepatic uptake after oral glucose". Again the assumption is made that peripheral glucose uptake is independent of the route of glucase administration. Somersalo [12] has shown that the presence of glucose in the intestine stimulates the assimilation of intravenous glucose, and Perley and Kipnis themselves showed that the high plasma insulin levels found with oral glucose were accompanied by a larger peripheral arteriovenous glucose difference than that which occurred with intravenous administration. Clearly the amount of infused glucose necessary to match the blood glucose levels of the oral test cannot be considered a close approximation to the quantity of oral glucose escaping initial hepatic uptake; such a figure would be a serious underestimate.

Blood glucose levels are a crude indicator of the metabolic relationships of circulating glucose. Not only is glucose removal important but also the rate at which the liver adds glucose to the blood. The design of our experiments was simple, and our results do not permit us to decide whether the relative contributions of the liver and the peripheral tissues in the disposal of administered glucose were the same with different routes of administration. Furthermore, it is possible that our failure to demonstrate superior glucose tolerance with intraportal administration may have been due to the conditions under which the experiments were performed; the high protein diet, anaesthesia and the metabolic response to surgery may all have adversely affected glucose tolerance and diminished our ability to demonstrate such a difference. Even so, the similarity of the blood glucose response with both routes of administration suggests that the importance of the anatomical relationship between the gut, portal vein and liver may have been overemphasized in studies of the metabolism of orally administered 
glucose. It is likely that the enhanced stimulation of insulin secretion which occurs with intestinal absorption of glucose is of much greater importance in determining the disposal of an orally administered load.

Acknowledgements: We should like to thank the British Insulin Manufacturers for help with expenses. We also wish to express our gratitude to Mrs. Diane Friesinger and Miss Rose Clarke for their invaluable assistance in the dog studies.

\section{References}

1. Cori, C.F., Cori, G.T.: The fate of sugar in the animal body. IV. The tolerance of normal and insulinized rats for intravenously injected glucose and fructose. J. biol. Chem. 72, 597-614 (1927).

2. De Filippi, F.: Der Kohlehydratsstoffwechsel bei Hunden, die mit Ecks Fistel, nach der Pawlowschen Methode (direkte Einführung des Pfortaderblutes in die Vena Cava mit Unterbindung der Pfortader) operiert wurden. Ztschr. f. Biol. 49, 511-557 (1907).

3. De Filippi, F.: Der Kohlehydratsstoffwechsel bei Hunden, die mit der Eckschen Fistel nach Pawlowscher Methode (direkte Einführung des Pfortaderblutes in die Vena Cava, mit Verschlafs der Pfortader am Leberhilus) operiert wurden. Ztschr. f. Biol. 50, 3874 (1908)

4. Higashi, A., Peters, L.: A rapid colorimetic method for the determination of inulin in plasma and urine. J. Lab. clin. Med. 35, 475-482 (1950).
5. Huggett, A.St.G., Nixon, D.A.: Use of glucose oxidase, peroxidase, and o-dianisidine in determination of blood and urinary glucose. Iancet 1953 II, 368-370.

6. Jacobson, C.: A study of the carbohydrate tolerance in Eck fistula and hypophysectomized animals (posterior lobe removal). Amer. J. Physiol. 32, 233-247 (1920).

7. Janes, R.G., Osburn, J.P.: The analysis of glucose measurements by computer simulation. J. Physiol. 181, 59-67 (1965).

8. MeIntyre, N., Holdsworth, C.D., Turner, D.S.: Intestinal factors in the control of insulin secretion. J. clin. Endocr. 25, 1317-1324 (1965).

9. Perley, M.M., Kipnis, D.M.: Plasma insulin response to oral and intravenous glucose: Studies in normal and diabetic subjects. J. clin. Invest. 46, 1954-1962 (1967).

10. Samols, E., Bilkus, D.: A comparison of insulin immunoassays. Proc. Soc. exp. Biol. (N.Y.) 115, 79 $84(1964)$

11. Scow, R.O., Cornfield, J.: Quantitative relations between the oral and intravenous glucose tolerance curves. Amer. J. Physiol. 179, 435-438 (1954).

12. Somersalo, O.: Staub effect in children. Acta Paediatrica. Suppl. 78, Helsinki (1950).

\author{
Neil MeIntyre \\ Medical Unit, \\ Royal Free Hospital \\ North Western Branch \\ Lawn Road \\ London, N.W. 3., Great Britain
}

